\title{
Correlation Level of Cardiac Troponin-I with Total Duration of Oxygen/ Ventilator Therapy in the Term New-borns with Respiratory Distress
}

\author{
Aleksandra Simović ${ }^{1,2 *}$ and Anđelka Stojković ${ }^{1,2}$ \\ ${ }^{1}$ Paediatric Clinic, Kragujevac, Serbia \\ ${ }^{2}$ Faculty of Medical Science, University of Kragujevac, Serbia
}

*Corresponding author: Aleksandra Simovic, Assistant Professor, Paediatric Clinic, Clinical Centre"Kragujevac", Faculty of Medical Science, University of Kragujevac, Zmaj Jovina 30, 34000 Kragujevac, Serbia, Tel: +381 34 370097; +381 63 1623191; Fax: +381 34 370213; E-mail: aleksandra.simovic@yahoo.com

Received date: May 14, 2014, Accepted date: August 25, 2014, Published date: September 1, 2014

Copyright: (c) 2014 Aleksandra Simovic et al. This is an open-access article distributed under the terms of the Creative Commons Attribution License, which permits unrestricted use, distribution, and reproduction in any medium, provided the original author and source are credited.

\begin{abstract}
Background: In spite of its potential clinical prognostic significance, only a small number of studies have been conducted to date involving neonatal cardiac troponin-I as an early indicator of significance respiratory dysfunction.

Objective: Aim of this study was to evaluate the clinical significance cardiac troponin-I as marker of cardiorespiratory failure in term newborns.

Methods: Cardiac troponin-I level was determined in serum (at 24-48 hours after birth) in 55 term neonates with respiratory distress and 36 healthy, term newborns. The cardiac troponin-I level is correlated with the total duration of oxygen and ventilatory therapy (expressed in days) in both groups with (13/55) or without (32/55) deaths.

Results: Newborns with respiratory distress had a significantly higher level of cardiac troponin-I, compared to the control group, with the largest increase in cardiac troponin-I observed in mechanically ventilated patients (31/55). The length of applied respiratory support was positively correlated with the level of cardiac troponin-I in survivors of respondents, while in the group of children who died the level of cardiac troponin-I was negatively correlated with total duration of respiratory support, and the number of days to death.
\end{abstract}

Conclusions: The increase in cardiac troponin-I could indicate the development of severe respiratory failure in term neonates with respiratory distress.

Keywords: Cardiac troponin I; Newborn; Respiratory distress; Perinatal asphyxia

\section{Abbreviations:}

RD: Respiratory Distress; cTnI: Cardiac Troponin-I; GA: Gestational Ages; BW: Body Weight in grams; AS: Appgar score at 5 min; MV: Mechanical Ventilation

\section{Introduction}

Markers of myocardial damage are the macromolecules, which after myocardial necrosis diffuse to the cardiac intersticium and microvasculature. The specificity of cardiac markers is reflected in high concentrations in the myocardium and absence in other tissues, while the sensitivity of these markers is reflected in speed of their release into the blood after myocardial damage [1]. Markers of myocardial necrosis, which is now commonly used in clinical practice are: creatine kinase and its isoenzyme creatine kinase-muscle, troponin I and T, lactate dehydrogenase, myoglobin, and others [2-5].

Troponin complex consists of three subunits that regulate the contractile process in muscle interfering calcium ions. The three subunits are: Troponin $\mathrm{C}(18 \mathrm{kD})$, which binds to calcium ions, Troponin I $(26 \mathrm{kD})$ that binds to actin and inhibits the reaction between actin and myosin and Troponin $\mathrm{T}(39 \mathrm{kD})$, which binds to tropomyosin. Troponin $\mathrm{T}$ and Troponin I are located in the heart and in the skeletal muscle, but are coded to different genes and have a different arrangement of amino acids, which enabled the production of antibodies specific to cardiac troponin form and determination in serum $[1,6-8]$.

Troponin is known to be able to grow in the absence of myocardial infarction, in conditions such as: trauma of myocardium, cardioversion, cateter ablation, cardiac arrest, postoperative myocardial damages, acute pericarditis, acute pulmonary embolism, acute or severe heart failure, myocarditis, cardiomyopathy and some congenital heart disease, toxic effect of drugs during for chemotherapy and others $[9,10]$.

On the other hand, increase in the value of Troponin can occur in other conditions outside of the heart: sepsis, renal or respiratory failure, hemolysis, and amyloidosis and also in situations where the Troponin is a false positive in the presence of rheumatoid factor, heterophile antibodies, fibrin etc. [4].

Determining the value of cardiac troponin I and T, as early diagnostic and prognostic indicators of critically ill term newborns with respiratory failure is the major focus of the scientific community today. The reasons why the poor prognosis associated with increased cardiac troponin is still not fully understood, hence the increase in efforts to shed light on the background of some of the mechanisms of the prognostic role of cardiac troponin [10]. 


\section{Objective}

The main objective of this study was to examine whether the increase in cardiac troponin-I (cTnI) in the first 24-48 hours after birth, can be used as an early screening of critically ill term newborns with cardio-respiratory failure, respectively:

1. Examine whether there is a significant difference in the cTnI level, between the groups of newborns with and without clinical signs of respiratory distress (RD);

2. To determine whether there is a significant difference in the level of cTnI between the ventilated and non-ventilated patients with $\mathrm{RD}$;

3. Examine whether the level of cTnI was correlated with the number of days of oxygen/ventilatory therapy (with special reference to the group of patients with fatal outcome).

\section{Materials and Methods}

The study was conducted at the Center of Neonatology, Pediatric Clinic and at the Maternity Gynaecology and Obstetrics Clinic, Clinical Center in Kragujevac, in the period from August 2007 by January 2010 year. In its character study was a retrospectiveprospective non-interventional. The diagnostic methods were not applied for the sole purpose of this study, but the diagnosis was carried out within the framework of reference and neonatal protocols that were approved by the parents in the form of written consent, and the decision of the Ethics Committee, the parent institution, and number 01-613.

Based on previously conducted pilot study, where the Fisher and Student t-test was used obtained statistically significant difference in the level of troponin I, as primary variables in the observed groups, (if a power of study is $80 \%$, and a level of statistical significance 0.05 ) using the statistical program, provided that the required number of subjects in the experimental group is 36 [11].

During the three-year study 108 patients were analyzed. Seventeen subjects were excluded.

\section{Criteria for exclusion from the study were:}

1. Congenital heart defect (1 hypoplastic left heart, a ventricular septal defect, pulmonary artery stenosis 1 and 2 atrial septal defect),

2. Chromosomal aberrations ( 1 and 2 Down Edwards syndrome), or

3. Congenital sepsis (9 patients with positive blood cultures).

\section{Criteria for inclusion of subjects in the study were as follows:}

1. Respiratory distress (tachypnea, inspiratory visible indentation of the soft tissues of the chest, cyanosis, and the emergence of expiratory sobbing) [12-14].

2. Apgar score $<4$ at 1 minute and $<7$ at 5 minute after birth $[15,16]$;

3. Metabolic acidosis (defined as a lactate level $>3.7 \mathrm{mmol} / \mathrm{l}$ in the first 1-12 hours after birth);

4. Absolute indication for conventional ventilation was a hypoxemia $\mathrm{PaO}<6,65 \mathrm{kPa}$ or $50 \mathrm{mmHg}$ and $\mathrm{FiO} 2>0,8$; hypercapnia $\mathrm{PaCO} 2>8.0 \mathrm{kPa}$ or $60 \mathrm{mmHg}$; $\mathrm{pH}<7,2$ and apnea longer than 20 seconds, according to the criteria Gligorovic S. from 1995 [17].
5. Maintenance of blood pressure below the tenth percentile for that gestational age and birth weight and / or oliguria $<1 \mathrm{ml} / \mathrm{kg}$ / hour, despite compensation the volume with colloidal solution, has been indication to use inotropes, according to the criteria from Cruz MA et al. from 2006 years [18].

The level of second-generation of troponin I (cTnI-ultra) in serum was determined in all patients in the first $24-48$ hours after birth with enzyme immunoassay method on the device Biomerieux mini Vidas, with technique ELFA ("enzyme- linket fluorescent assay"). In the adult population, the normal level (99th percentile), for this type of apparatus is cTnI-ultra $<0.01 \mu \mathrm{g} / \mathrm{l}$, with the coefficient of variation of $10 \%$ (from $0.01-0.11 \mathrm{mg} / \mathrm{l}$ ) [19]. The reference values for the second generation of troponin I are still not know for the neonatal population, whereas the first generation $\mathrm{cTnI}$ reference range varies from $0.01-3$ $\mathrm{mg} / \mathrm{l}$, depending on the authors (Bader D et al. 2006, Trevisanuto D. et al 2006, Mc Auliffe et al. 2004, Clark SJ et al 2001. and other) [20-24].

\section{Statistical Analysis}

For the analysis of basic clinical characteristics of the respondents the descriptive statistics such as arithmetic mean, standard deviation and percentages were used. For comparison of mean values of two variables of the population the Mann-Whitney test-ev was used. The correlation between the two numerical characteristics was studied using Spearman correlation coefficient, and the receiver operating characteristic (ROC) curve for determining cut off values for different markers. The analyses were performed in SPSS 14.0 for Windows. Results were considered statistically significant at the $5 \%$ level.

\section{Results}

The study included 91 infants born at term. These infants were divided into two main groups (Table 1):

1. First group - 55 patients with clinical signs of respiratory distress, mean gestational age $39.5 \pm 1.32$ weeks, average Apgar score at 5 minute $4.704 \pm 2.186$; (median 5) and lactate levels of $8.63 \pm 4.43$ $\mathrm{mmol} / \mathrm{l}$, median $7.6(4.8-13.3) \mathrm{mmol} / \mathrm{l}$; use of conventional mechanical ventilation required a $31 / 55$ or $56.36 \%$; use of inotropes (dopamine) required $23 / 55$ or $41.82 \%$ of respondents; the outcome was fatal in $13 / 55$ or $23.64 \%$ of respondents;

2. Second group - 36 healthy, term newborns, mean gestational age $39.8 \pm 1.089$ weeks, average Apgar score at $5 \mathrm{~min} 8.94 \pm 0.41$; (median 9) and the mean lactate levels $1.0388 \pm 0.36 \mathrm{mmol} / \mathrm{l}$, median $0.9(0.8-1.2) \mathrm{mmol} / \mathrm{l}$. All the patients were with normal clinically status.

3. Other clinical characteristics of the respondents surveyed are shown in Table 1.

\begin{tabular}{|c|c|c|}
\hline Clinical characteristics of $(n=91)$ & $\begin{array}{l}\text { New borns with } \\
\operatorname{RD}(n=55)\end{array}$ & $\begin{array}{l}\text { Healthy new } \\
\text { borns }(n=36)\end{array}$ \\
\hline Male (\%) & $31 / 55(56.36)$ & $17 / 36(47.22)$ \\
\hline Female (\%) & $24 / 55(43.64)$ & $19 / 36(52.78)$ \\
\hline Gestational ages in weeks $(x \pm S D)$ & $39.5 \pm 1.32$ & $39.8 \pm 1.089$ \\
\hline BW in kilogram $(x \pm S D)$ & $3.4298 \pm 0.5713$ & $3.455 \pm 0.352$ \\
\hline Appgar score in 5-minute $(x \pm S D)$ & $4.704 \pm 2.186$ & $8.94 \pm 0.41$ \\
\hline The level of the lactats $\mathrm{mmol} / \mathrm{l}(\mathrm{x} \pm \mathrm{SD})$ & $8.63 \pm 4.43$ & $1.0388 \pm 0.36$ \\
\hline
\end{tabular}


Citation: Simovic A, Stojkovic A (2014) Correlation Level of Cardiac Troponin-I with Total Duration of Oxygen/Ventilator Therapy in the Term New-borns with Respiratory Distress. J Cardiovasc Dis Diagn 2: 172. doi:10.4172/2329-9517.1000172

Page 3 of 5

\begin{tabular}{|l|l|l|}
\hline O2 therapy $(>28$ days $)$ & $8 / 55(14.54)$ & $0 / 36(0)$ \\
\hline Number of days of O2 $(x \pm S D)$ & $15.46 \pm 17.27$ & 0 \\
\hline Application of MV $(\%)$ & $31 / 55(56.36)$ & $0 / 36(0)$ \\
\hline Number of days of MV $(x \pm S D)$ & $5.679 \pm 8.419$ & 0 \\
\hline The application of inotropes $(\%)$ & $23 / 55(41.82)$ & 0 \\
\hline Died $(\%)$ & $13 / 55(23.64)$ & $0 / 36(0)$ \\
\hline
\end{tabular}

Table 1: Basic clinical characteristics of respondents in observed groups.

Note: RD-respiratory distress, BW-body weight, $\mathrm{O}_{2}$ - oxygen therapy, MV-conventional mechanical ventilation

4. In the group of term neonates with $\mathrm{RD}$, a significant increase in $c \operatorname{TnI}$ serum $(\mathrm{p}<0.005)$ was observed (median 0.07 , with a range from $0.01-0.16 \mu \mathrm{g} / \mathrm{l})$, compared to the control group: median $0.01(0.01-0.01) \mu \mathrm{g} / \mathrm{l}$. Calculated area under the ROC curve for cTnI=0.816; $\mathrm{p}<0.0005 ; \quad$ (cut off $0.045 \mu \mathrm{g} / \mathrm{l} ;$ Sensitivity $75 \%$ Specificity $84,3 \%$ ), suggesting that $\mathrm{cTnI}$ is a very sensitive marker for prediction of respiratory dysphunction (Figure 1).

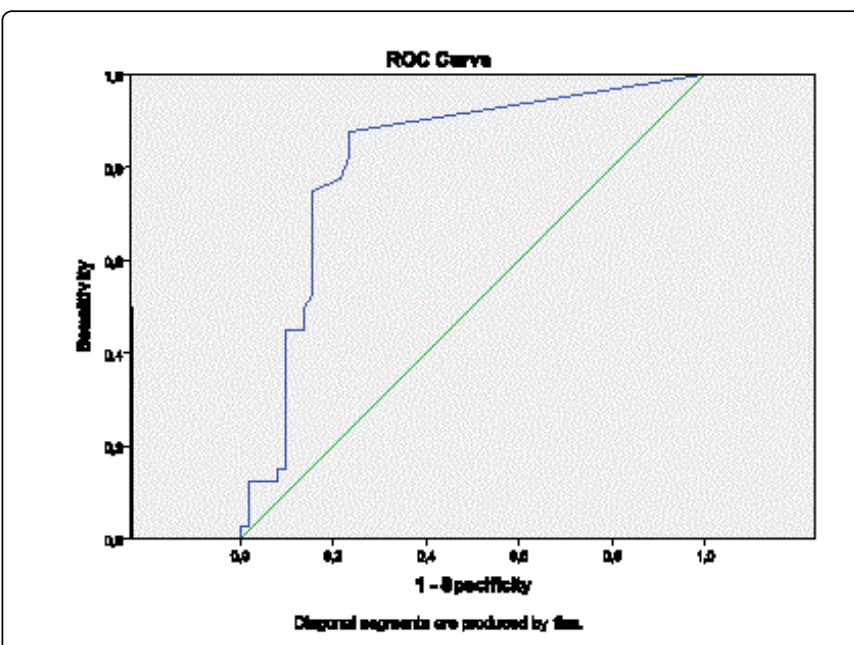

Figure 1: Predictive value of cardiac Troponin-I for the respiratory distress: sensitivity and specificity

5. Mann-Whitney test showed that the group of mechanically ventilated infants with $\mathrm{RD}$ cTnI level was significantly higher (median $0.11 \mu \mathrm{g} / \mathrm{l}$; the range of from $0.04-0.18 \mu \mathrm{g} / \mathrm{l} ; \mathrm{p}=0.039$ ), compared to non-ventilated infants with RD (median $0.035 \mu \mathrm{g} / \mathrm{l}$, with a range of from $0.01-0.135 \mu \mathrm{g} / \mathrm{l}$ ). Calculated area under the ROC curve for $c T n I=0.800 ; p<0.0005$; cut off level cTnI for conventional mechanical ventilation was $0,055 \mu \mathrm{g} / \mathrm{l}$; Sensitivity $71 \%$ Specificity $87.83 \%$ (Figure 2).

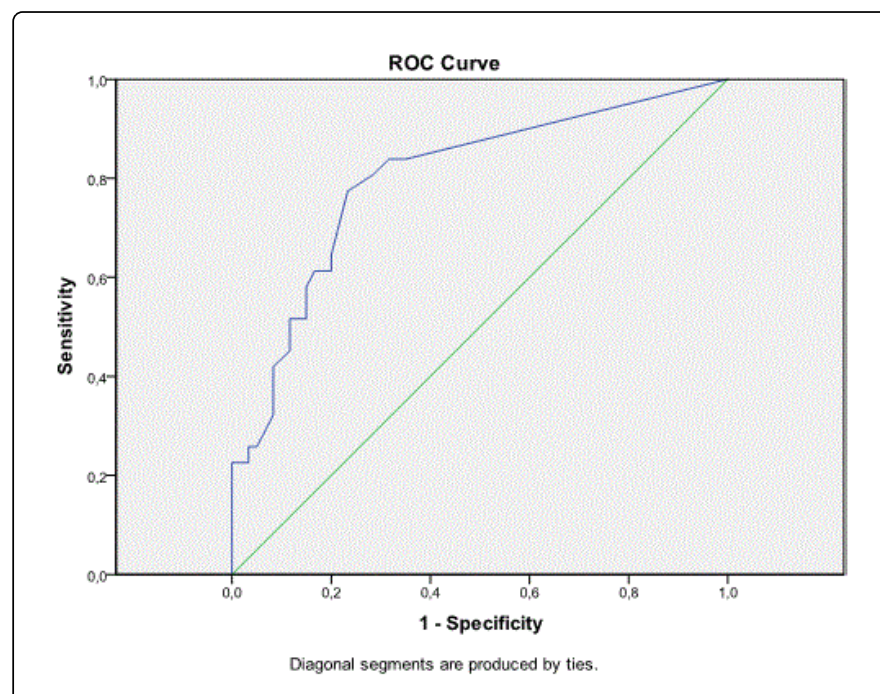

Figure 2: Predictive value of cardiac Troponin I for the conventional mechanical ventilation: sensitivity and specificity

Also, in critically ill infants who were hypotensive requiring inotropic therapy (dopamine in the dose of $5 \mu \mathrm{g} / \mathrm{kg} / \mathrm{min}$ ) significant increase in cTnI was observed (median $0.15 \mu \mathrm{g} / \mathrm{l}$; with a range from 0.06-0.56 $\mu \mathrm{g} / \mathrm{l} ; \mathrm{p}=0.006)$ compared to normotensive, infants with $\mathrm{RD}$ $(0.035 \mu \mathrm{g} / \mathrm{l}$, with a range from $0.01-0.137 \mu \mathrm{g} / \mathrm{l})$.

Surviving patients with early growth in cTnI demanded longer useful respiratory support, compared to subjects in which the level cTnI ranged from reference values (Table 2).

\begin{tabular}{|l|l|l|}
\hline The observed parameter & $\mathbf{c T n l}(\mathbf{r})$ & $\mathbf{p}^{*}$ \\
\hline No. $\mathrm{O}_{2}$ days & 0,273 & $<0,0005$ \\
\hline No. MV days & 0,273 & $<0,0005$ \\
\hline
\end{tabular}

Table 2: Correlation of cardiac troponin I with duration of oxygen therapy/ conventional mechanical ventilation, demonstrated by the correlation coefficients in the group forward asphyxial infants without fatal outcome

Note: $\mathrm{p}^{*}$ - significant significance at level $\mathrm{p}<0,01$ (2- degree of freedom); cTnI - cardiac troponin I; r - correlation coefficients; Number of $\mathrm{O}_{2}$ days - Total duration of oxygen therapy, expressed in days; Number of MV days - total duration of conventional mechanical ventilation in days

On the other hand, the group of patients with fatal cTnI level was negatively correlated with total duration of respiratory support, and the number of days to death (Table 3 ).

\begin{tabular}{|l|l|l|}
\hline The observed parameter & CTnl $(r)$ & $p^{*}$ \\
\hline No. $O_{2}$ days & $-0,316$ & 0,132 \\
\hline No. MV days & $-0,406$ & 0,044 \\
\hline
\end{tabular}

Table 3: Correlation of cardiac troponin I with duration of oxygen therapy / conventional mechanical ventilation in the group of patients with fatal outcome, demonstrated by the correlation coefficients 
Note: $\mathrm{p}^{*}$ : significant correlation at the level of $\mathrm{p}<0.05 ; \mathrm{cTnI}$ - cardiac troponin I; $\mathrm{r}$ - correlation coefficients

\section{Discussion}

Acute hypoxia and/or hypoxemia and decrease in blood $\mathrm{pH}$ further reduce surfactant synthesis, and therefore perinathal asphyxia favors the appearance respiratory distress $[12,13,17]$.

In the newborn children with post asphyxial sindrome delayed initiation of respiration leads to respiratory and metabolic acidosis, which results in increased pulmonary vascular resistance preventing the increase of blood flow through the lungs. Hypoxic pulmonary capillary damage causes them to leak and backflow water into the tissues.

Post-asphyctic heart failure can lead to pulmonary edema, which leads to increase of cardiac markers, as shown in studies [9,20,25].

Similar to other authors [10] and our study observed a significant increase of cTnI in patients with postasphyxial syndrome and RD.

Early growth in $\mathrm{cTnI}(>0,045 \mu \mathrm{g} / \mathrm{l})$ is significantly correlated with respiratory distress $(\mathrm{r}=0.326, \mathrm{p}=0.04)$, whereas the level of cardiac troponin was significantly higher in the group of critically ill, mechanical ventilation and / or hypotensive infants $[20,26]$.

Also, the level of cTnI was positively correlated with total duration of oxygen therapy, or No. of days on conventional mechanical ventilation, similar to the results $\mathrm{H}$. Awada and associates [27].

Although it was a somewhat weaker correlations, they still indicated that the early increase in $\mathrm{cTnI}(>0,055 \mu \mathrm{g} / \mathrm{l})$ was more pronounced, and asphyxial infants subsequently required longer mechanical ventilation or oxygen therapy.

On the other hand, when we separated the patients with fatal outcome, the cTnI level was negatively correlated with total duration of mechanical ventilation. In the group of infants with fatal outcome, the number of days of conventional mechanical ventilation was the same as days to death. This means that the greater increase in serum cTnI in the first 24-48 hours after birth was observed in the subjects that lived shorter.

These results indirectly suggest that the early rise in serum levels cTnI can be used as an indicator of critically ill children [28-32]. Early detection would enable the timely treatment of newborns with different degrees of respiratory failure and could prevent a fatal outcome.

\section{Conclusion}

In the group of term newborns with respiratory distress, the level of cTnI significantly was higher than in the group of healthy, term newborns. Early growth in cTnI levels is significantly correlated with different degrees of respiratory failure, with significantly higher cTnI reported in critically ill, mechanically ventilated newborn infants. Patients with early growth in cTnI required a much longer useful respiratory support, compared to subjects in which the level cTnI ranged from normal values, which indirectly points to the fact that cTnI can be used in the prognosis of cardio-respiratory failure.

\section{References}

1. Nada Majkic-Singh $\mathrm{T}$ (2003) Primena biohemijskih markera za dijagnostikovanje akutnog koronarnog sindroma. Jugoslovenska medicinska biohemija 22: 289-301.

2. Antman M, Braunwald E (2001) Acute myocardial infarction. In: Braunwald E, Zipes DP, Libby P, Eds. Heart Disease: A Textbook of Cardiovascular Medicine. (6th Edn.), Philadelphia: W.B. Saunders, USA 1114-1219.

3. Milutinovic S, Karadžic R, Pavlovic M, Tomaševic M, Stankovic A (2006) Primena biohemijskih markera u kardiologiji. Apollinem medicum et aesculapium 4: 16-22.

4. Roongsritong C, Warraich I, Bradley C (2004) Common causes of troponin elevations in the absence of acute myocardial infarction: incidence and clinical significance. Chest 125: 1877-1884.

5. Bhayana V, Henderson AR (1995) Biochemical markers of myocardial damage. Clin Biochem 28: 1-29.

6. Hetland O, Dickstein K (1998) Cardiac troponins I and T in patients with suspected acute coronary syndrome: a comparative study in a routine setting. Clin Chem 44: 1430-1436.

7. Panteghini M, Agnoletti G, Pagani F, Spandrio M (1997) Cardiac troponin $\mathrm{T}$ in serum as marker for myocardial injury in newborns. Clin Chem 43: 1455-1457.

8. Setiadi BM, Lei H, Chang J (2009) Troponin not just a simple cardiac marker: prognostic significance of cardiac troponin. Chin Med J (Engl) 122: 351-358.

9. Shelton SD, Fouse BL, Holleman CM, Sedor FA, Herbert WN (1999) Cardiac troponin T levels in umbilical cord blood. Am J Obstet Gynecol 181: 1259-1262.

10. www.quantitativeskills.com/sisa/calculations/samsize.htm

11. Zupan Simunek V (2008) [Definition of intrapartum asphyxia and effects on outcome]. J Gynecol Obstet Biol Reprod (Paris) 37: 7-15.

12. Carter BS, Haverkamp AD, Merenstein GB (1993) The definition of acute perinatal asphyxia. See comment in PubMed Commons below Clin Perinatol 20: 287-304.

13. Fanaroff A, Martin R, Walsh M (2011) Diseases of the fetus and infant. In: Fanaroff and Martin's Neonatal-perinatal medicine, (9th Edn.), Volume 1. Mosby Elsevier, USA.

14. Carter BS, McNabb F, Merenstein GB (1998) Prospective validation of a scoring system for predicting neonatal morbidity after acute perinatal asphyxia. J Pediatr 132: 619-623.

15. Groenendaal F, de Vries LS (2000) Selection of babies for intervention after birth asphyxia. Semin Neonatol 5: 17-32.

16. Gligorovic S (1981) Perinatal asphyxia and reanimation. Belgrade: Medicinski fakultet Univerziteta u Beogradu; Thesis (Serbian).

17. Cruz MA, Bremmer YA, Porter BO, Gullquist SD, Watterberg KL, et al. (2006) Cardiac troponin $\mathrm{T}$ and cardiac dysfunction in extremely lowbirth-weight infants. Pediatr Cardiol 27: 396-401.

18. Apple FS (2009) A new season for cardiac troponin assays: it's time to keep a scorecard. Clin Chem 55: 1303-1306.

19. Baum H, Hinze A, Bartels P, Neumeier D (2004) Reference values for cardiac troponins $\mathrm{T}$ and $\mathrm{I}$ in healthy neonates. Clin Biochem 37: 1079-1082.

20. Trevisanuto D, Picco G, Golin R, Doglioni N, Altinier S, et al. (2006) Cardiac troponin I in asphyxiated neonates. Biol Neonate 89: 190-193.

21. Araújo K, da Silva J, Sañudo A, Kopelman B (2004) Plasma concentrations of cardiac troponin I in newborn infants. Clin Chem 50: 1717-1718.

22. Clark SJ, Newland P, Yoxall CW, Subhedar NV (2001) Cardiac troponin $\mathrm{T}$ in cord blood. Arch Dis Child Fetal Neonatal Ed 84: F34-37.

23. Katiací Araújo, José da Silva, Adriana Sañudo, Benjamin Kopelman (2004) Plasma concentrations of cardiac troponin I in newborn infants. Clin Chem 50: 9. 
Citation: Simovic A, Stojkovic A (2014) Correlation Level of Cardiac Troponin-I with Total Duration of Oxygen/Ventilator Therapy in the Term New-borns with Respiratory Distress. J Cardiovasc Dis Diagn 2: 172. doi:10.4172/2329-9517.1000172

Page 5 of 5

24. Clark SJ, Newland P, Yoxall CW, Subhedar NV (2004) Concentrations of cardiac troponin $\mathrm{T}$ in neonates with and without respiratory distress. Arch Dis Child Fetal Neonatal Ed 89: 348-352.

25. Kelley WE, Januzzi JL, Christenson RH (2009) Increases of cardiac troponin in conditions other than acute coronary syndrome and heart failure. Clin Chem 55: 2098-2112.

26. Rivara MB, Bajwa EK, Januzzi JL, Gong MN, Thompson BT, et al. (2012) Prognostic Significance of Elevated Cardiac Troponin-T Levels in Acute Respiratory Distress Syndrome Patients. Plosone.

27. Awada H, Al-Tannir M, Ziade MF, Alameh J, El Rajab M (2007) Cardiac troponin T: a useful early marker for cardiac and respiratory dysfunction in neonates. Neonatology 92: 105-110.

28. Caliskan E, Doger E, Cakiroglu Y (2006) Cord Blood Cardiac Troponin I and Creatine Kinase MB in Poor Outcomes. J Turkish German Gynecol Assoc 7: 98-102.
29. Lipshultz SE, Rifai N, Sallan SE, Lipsitz SR, Dalton V, et al. (1997) Predictive value of cardiac troponin $\mathrm{T}$ in pediatric patients at risk for myocardial injury. Circulation 96: 2641-2648.

30. El-Khuffash AF, Molloy EJ (2008) Serum troponin in neonatal intensive care. Neonatology 94: 1-7.

31. Simovic AM, Knezevic J, Igrutinovic Z, Stojanovic N, Kocic S (2009) Cardiac troponin as biochemical marker of perinatal asphyxia and hypoxic myocardial injury. Vojnosanit Pregl 66: 881-886.

32. Turker G, Saper N, Babaoglu K, Gökalp AS, Duman C, et al. (2005) Early prognostic significance of umbilical cord troponin I in critically ill newborns. Prospective study with a control group. J Perinat Med 33: 54-59. 